\title{
Interleukin-10 is Differentially Expressed in the Small Intestine and the Colon Experiencing Chronic Inflammation and Ulcerative Colitis Induced by Dextran Sodium Sulfate in Young Pigs
}

\author{
D. LACKEYRAM ${ }^{1,2}$, D. YOUNG ${ }^{3}$, C. J. KIM ${ }^{3}$, C. YANG ${ }^{1,4}$, T. L. ARCHBOLD ${ }^{1}$, Y. MINE ${ }^{3}$, \\ M. Z. FAN ${ }^{1}$
}

${ }^{1}$ Department of Animal Biosciences, University of Guelph, Guelph, Ontario, Canada, ${ }^{2}$ Open Learning and Educational Support, University of Guelph, Guelph, Ontario, Canada, ${ }^{3}$ Department of Food Science, University of Guelph, Guelph, Ontario, Canada, ${ }^{4}$ Department of Animal Science, University of Manitoba, Winnipeg, Manitoba, Canada

Received November 11, 2015

Accepted May 27, 2016

On-line October 26, 2016

\section{Summary}

Intestinal inflammation induced with dextran sodium sulfate (DSS) is used to study acute or chronic ulcerative colitis in animal models. Decreased gut tissue anti-inflammatory cytokine IL-10 concentration and mRNA abundance are associated with the development of chronic bowel inflammation. Twelve piglets of 3 days old were fitted with an intragastric catheter and randomly allocated into control and DSS groups by administrating either sterile saline or $1.25 \mathrm{~g}$ of DSS/kg body weight (BW) in saline per day, respectively, for 10 days. Growth rate and food conversion efficiency were reduced $(p<0.05)$ in the DSS piglets compared with the control group. Quantitative histopathological grading of inflammation in the jejunum and colon collectively showed that the DSS treatment resulted in 12 fold greater $(p<0.05)$ inflammation severity scoring in the colon than in the jejunum, indicative of chronic ulcerative colitis in the colon. Upper gut permeability endpoint was 27.4 fold higher $(p<0.05)$ in the DSS group compared with the control group. The DSS group had higher concentrations and mRNA abundances $(p<0.05)$ of TNF- $\alpha$ and IL-6 in the jejunal and colonic tissues compared with the control group. Colonic concentration and mRNA abundance of IL-10 were reduced $(p<0.05)$, however, jejunal IL-10 mRNA abundance was increased $(p<0.05)$ in the DSS group compared with the control group. In conclusion, administration of DSS at $1.25 \mathrm{~g} / \mathrm{kg}$ BW for 10 days respectively induced acute inflammation in the jejunum and chronic inflammation and ulcerative colitis in the colon with substantially decreased colonic concentration and mRNA abundance of IL-10 in the young pigs, mimicking the IL-10 expression pattern in humans associated with chronic bowel inflammation.

\section{Key words}

Chronic bowel inflammation • Cytokine • Gut permeability • IL-10

- Colonic ulcerative colitis

\section{Corresponding author}

M. Z. Fan, Department of Animal Biosciences, Building \#70, University of Guelph, Guelph, Ontario, Canada N1G 2W1. E-mail: mfan@uoguelph.ca

\section{Introduction}

Inflammatory bowel disease (IBD) is a chronic disorder of the gastrointestinal tract that causes abdominal pain and discomfort together with altered bowel habits such as diarrhea (Murch et al. 1991, Cohen et al. 2004, Longstreth et al. 2006). Two major forms of IBD that have been well characterized are ulcerative colitis and Crohn's disease. While ulcerative colitis is always restricted to the colon and involves the rectum, Crohn's disease can occur at any location in the intestinal tract with the highest incidences reported in ileum, cecum and colon (Leenen and Dieleman 2007).

Acute ulcerative colitis could be established within 4-5 days of consumption of an effective dose of DSS in rodents and pigs (Tsune et al. 2003, Kim et al. 
2009, Sánchez-Fidalgo et al. 2010, Young et al. 2010). Chronic ulcerative colitis was induced after administration of DSS for 3-5 weeks in rodents (Okayasu et al. 1990, Sánchez-Fidalgo et al. 2010). No studies have been conducted to establish the DSS induction of chronic bowel inflammation associated with chronic ulcerative colitis through profiling IL-10 gene expression. It has been shown that the gut microflora in monogastric animals can be re-established within 10 days (Sonnenburg et al. 2005). A life span for intestinal epithelial cells, including intraepithelial lymphocytes, of young pigs was estimated to be within 5-10 days from our previous studies (Fan et al. 2001). Thus, we hypothesized that administration of an effective dose of DSS for 10 days would be a minimal time period to induce chronic bowel inflammation responses and chronic ulcerative colitis in the colon of young pigs. Therefore, the primary objectives of this study were to investigate if chronic inflammation responses associated with chronic ulcerative colitis in the colon of young pigs could be induced through intra-gastric (ig) infusion of an effective dose of DSS for 10 days through comparatively profiling IL-10 and representative pro-inflammatory cytokine gene expression in both the colon and the small intestine.

\section{Materials and Methods}

\section{Animals, diets, surgery and experimental design}

A total of 12 purebred Yorkshire gilts at the age of day 3 were obtained from the University of Guelph Arkell Swine Research Station and were transferred into the Animal Wing in the Department of Animal Biosciences at the university. After two days of adaptation to a commercial milk replacer (Soweena ${ }^{\circledR}$ Litter Life - Merrick's Inc., WI, UAS) (Fan et al. 2001), piglets were surgically fitted with an ig catheter (MicroRenathane $^{\circledR}$, O.D. $0.8 \mathrm{~mm}$, Braintree Scientific, Inc., MA, USA), and allowed a 3-day post surgical recovery for regaining their normal level of food intake. Each ig catheter was anchored to a trimmed inert silicone anchor (about $8 \times 12 \mathrm{~mm}$; Access Technologies, Skokie, IL) that was further sutured onto the gastric wall with the catheter end of about $30 \mathrm{~mm}$ inserted inside the gastric environment. Each piglet was then dressed in a custommade infusion jacket with a dorsal pocket for temporary storage of the exterior segment of the catheter. The piglets were then randomly assigned into a control group $(n=6)$ and a DSS-treatment $(n=6)$ group. One piglet was lost due to surgical complication and/or adaptation to DSS infusion, resulting in five observations for the DSS group. The piglets were fed close to their ad libitum intake level three times daily at 09:00, 12:00 and 16:00 h. Daily food intake and initial and final body weights (BW) were measured for all the piglets. All animal handling procedures were approved by the Animal Care Committee at the University of Guelph. The animal trial in this study was conducted in accordance with the guidelines established by Canadian Council of Animal Care (Candian Council on Animal Care 1993).

\section{Intra-gastric injection protocols}

Piglets in both groups were infused via the ig catheter with an equal volume (10 ml/piglet.day) of either sterile saline (control group) or $1.25 \mathrm{~g}$ of DSS $/ \mathrm{kg} \mathrm{BW.day}$ with DSS (MW, 36,000-50,000; MP Biomedicals, Solon, $\mathrm{OH}, \mathrm{USA}$ ) solubilized in sterile saline (DSS group). The DSS dose used in this study was based from studies reported in piglets (Mackenzie et al. 2003, BassaganyaRiera and Hontecillas 2006, Kim et al. 2009, Young et al. 2010). Both saline and DSS solutions were pre-warmed at $37{ }^{\circ} \mathrm{C}$ in a water bath. The ig injections were consistently administered twice daily following the morning and the afternoon meals for a period of 10 days.

In vivo stomach-small intestine-specific permeability test, sample collection and processing

In vivo gut permeability was measured by using a non-metabolizable monomer permeability marker D-mannitol according to an established protocol (Thymann et al. 2006). A linear increase in D-mannitol concentration in plasma within approximately $90 \mathrm{~min}$ after a bolus injection of D-mannitol was observed in the previous study with piglets (Thymann et al. 2006). Previous studies demonstrated that a total digesta retention time in the stomach and the small intestine of suckling piglets is between 6 and $9 \mathrm{~h}$ (Kidder and Manners 1978, Snoeck et al. 2004). Thus, 70-min time course was chosen to probe the stomach-small intestinespecific in vivo permeability to D-mannitol in this study. At the end of the DSS-treatment period, both groups of piglets were injected with a bolus dose $(0.6 \mathrm{~g}$ D-mannitol/kg BW solubilized in saline) of D-mannitol (Sigma/Aldrich, St. Louis, MO, USA) in a total injection volume at about $13 \mathrm{ml} / \mathrm{kg} \mathrm{BW}$ via an ig catheter. Blood samples were collected by puncture of the orbital sinus into pre-chilled centrifuge tubes containing heparin (Sigma/Aldrich) immediately prior to the injection of 
D-mannitol and this sample collection was designated to be the zero time point. Blood was also collected at 35 and 70 min post-injection, respectively. In order to minimize background interference, aliquot plasma samples were further cleared out, prior to D-mannitol analysis, for polymer organic compounds, including proteins, RNA and DNA. This was conducted by boiling glass sample test tubes in a water bath for 3-5 min followed by centrifugation at $21000 \mathrm{~g}$ for $60 \mathrm{~min}$ on a micromax microcentrifuge (International Equipment Company, Needham Heights, MA, USA). Plasma D-mannitol analysis was adapted from previous methods (Lunn et al. 1989, Graefe et al. 2003). D-Mannitol (0-40 nmol/incubation) in standards and plasma samples was analyzed by spectrophotometry at $340 \mathrm{~nm}$ by monitoring NADH yield after incubations with D-mannitol dehydrogenase (Megazyme International Ireland LTD., Co. Wicklow, Ireland) at $\mathrm{pH} 8.6$ and $40{ }^{\circ} \mathrm{C}$.

Subsequent to the bolus injection of D-mannitol and blood sampling for the in vivo upper gut permeability test, piglets were sedated by inhalation of anesthetic isoflurane for tissue sampling and were euthanized by using sodium pentobarbital (Graefe et al. 2003). Intestinal tissues were immediately removed and rinsed thoroughly in an ice-cold saline (154 mM NaCl at $\mathrm{pH} 7.4)$ containing a protease inhibitor phenylmethysulfonyl fluoride (PMSF) (0.1 mM; Sigma/Aldrich). Representative tissues were taken for gut mucosal morphological and histopathological measurements. Gut tissues were also immediately sampled and flash frozen in liquid nitrogen. The flash frozen tissue samples were further pulverized to be homogenous under liquid nitrogen using a pair of mortar and pestle and were sub-sampled and stored at $-80{ }^{\circ} \mathrm{C}$ for further analyses (Lackeyram et al. 2010).

\section{Histology and histopathology measurements}

Cross sections of both proximal jejunal and colonic tissues were fixed in $10 \%$ formalin for $12 \mathrm{~h}$, paraffin-embedded, and then stained with haematoxylin and eosin (Fan et al. 2001). The villous height, crypt depth and smooth muscle thickness were measured using the Openlab ${ }^{\mathrm{TM}}$ software (Improvision, Coventry, UK) (Lackeyram et al. 2010). Three jejunal and colonic tissue sections from each piglet were histopathologically blind-graded by two trained individuals. The quantitative histopathological grading used to assess the degree of inflammation was adopted from previous studies (Dieleman et al. 1998, Kim et al. 2009, 2010, Young et al. 2010). The scoring of the endpoints is described briefly as follows: occurrence of inflammation $(0=$ none, $1=$ slight, $2=$ moderate and $3=$ transmural); extent of inflammation $(0=$ none, $1=$ mucosa, $2=$ mucosa and submucosa and $3=$ transmural); degree of tissue regeneration $(0=$ complete regeneration or appearance of normal tissue, $1=$ almost complete regeneration, $2=$ basal $2 / 3$ damaged, $3=$ only surface epithelium intact and $4=$ entire crypt and epithelium lost), and crypt damage $(0=$ no damage, $1=$ basal $1 / 3$ damage, $2=$ basal $2 / 3$ damaged, $3=$ only surface epithelium intact and $4=$ entire crypt and epithelium lost) (Dieleman et al. 1998). The percentage contribution of each endpoint was scored ( $1=$ up to $25 \%, 2=26-50 \%, 3=51-75 \%$ and 4=76-100\%) (Dieleman et al. 1998). Each of the 4 graded endpoints was then multiplied by the percentage contribution score (1-4) to yield scoring ranges (0-12) for inflammation and the extent of inflammation, and scoring ranges (0-16) for regeneration and crypt damage (Dieleman et al. 1998).

\section{ELISA for cytokines}

Porcine specific kits for the analyses of TNF- $\alpha$, IL-6 and IL-10 cytokine contents in the intestinal tissues and plasma samples were purchased from Quantikine ${ }^{\circledR}$ (R\&D Systems Inc., Minneapolis, MN, USA). Crude tissue homogenate was prepared by homogenizing $0.5 \mathrm{~g}$ of jejunal and colonic tissues with a Powergen 125 hand-held tissue homogenizer (Fisher, Pittsburgh, PA, USA) in $1 \mathrm{ml}$ of Hank's buffer of balanced salt mixture without phenol red, calcium and magnesium (HyClone, Logan, UT, USA) but with $1 \mu 1$ of protease inhibitor cocktail. The cocktail included the following protease inhibitors $(\mathrm{mM}): \quad 0.02 \quad$ N-tosyl-L-phenylalanine chloromethyl-ketone; $0.02 \mathrm{~N}-\alpha$-p-tosyl-L-lysine ketone; 0.02 leupeptin hemisulfate; 0.02 apoprotinin; 0.02 pepstatin A and 0.1 PMSF (Sigma/Aldrich). The homogenate was immediately centrifuged at $12000 \mathrm{~g}$ at $4{ }^{\circ} \mathrm{C}$ and $100 \mu \mathrm{l}$ of the supernatant (about $0.8 \mathrm{mg}$ protein/sample) was used to initiate the ELISA incubation according to the instructions on the specific kit and absorbance was read by using a BioRad Model 550 Microplate reader (BioRad, Hercules, CA, USA). Protein contents in the supernatant and plasma samples were measured by using a Bio-Rad commercial kit (Lackeyram et al. 2010).

$R N A$ preparation and real time RT-PCR for cytokine $m R N A$

Total cellular RNA was extracted from 
pulverized porcine proximal jejunal and colonic tissue samples using TRIzol reagent (Invitrogen Corporation Life Technologies, Carlsbad, CA, USA). The RNA quality was checked through our established procedures including by $1 \%$ agarose gel electrophoresis stained with $10 \mu \mathrm{g} / \mathrm{ml}$ ethidium bromide and had an OD260:OD280 ratio between 1.8 and 2.0 (Lackeyram et al. 2010). About $1 \mu \mathrm{g}$ RNA per sample was treated with DNase (Invitrogen) according to the manufacturer's instructions and quantitative real time RT-PCR $(0.1 \mu \mathrm{g}$ cDNA/sample) was performed in a Smart Cycler (Cepheid, Sunnyvale, CA, USA) using Quantitect SYBR Green RT-PCR kit (Qiagen Inc., Valencia, CA, USA) according to instructions to the kit. Primers for the porcine TNF- $\alpha$, IL-6, IL-10 and $\beta$-actin (housekeeping gene control) were designed with the Primer 3 software (http://frodo.wi.mit.edu) and shown in Table 1. Equal amounts of DNase I-treated RNA were added to a total volume of $25 \mu$ l containing $12.5 \mu \mathrm{l}$ SYBR Green mixture, $0.25 \mu \mathrm{RT}$ mixture and $1 \mu \mathrm{M}$ of each of the forward and the reverse primers. We used the following protocol: (i) denaturation program $\left(15 \mathrm{~min}\right.$ at $\left.95^{\circ} \mathrm{C}\right)$; (ii) amplification and quantification program, repeated 45 cycles $\left(15 \mathrm{~s}\right.$ at $95^{\circ} \mathrm{C}, 15 \mathrm{~s}$ at $58^{\circ} \mathrm{C}, 15 \mathrm{~s}$ at $\left.72^{\circ} \mathrm{C}\right)$; and (iii) melting curve program $\left(60-99{ }^{\circ} \mathrm{C}\right.$ with a heating rate of $0.1^{\circ} \mathrm{C} / \mathrm{s}$ and fluorescence measurement). Negative controls were performed in which water was substituted for RNA. Melting curve analysis was conducted to confirm the specificity of each product, and the size of product was verified on ethidium bromide-stained $2 \%$ agarose gels in Tris-acetate-EDTA buffer (Rideout et al. 2007).

Table 1. Primer sequences used for the real time RT-PCR analyses. ${ }^{1}$

\begin{tabular}{|c|c|c|c|c|c|c|}
\hline Gene & Sequence (5'-3') & Primer size & Tm value & Location & $\begin{array}{c}\text { Product } \\
\text { size }\end{array}$ & $\begin{array}{c}\text { Accession } \\
\text { number }\end{array}$ \\
\hline \multirow{2}{*}{$T N F-\alpha$} & FP: atggatgggtggatgagaaa & $20 b p$ & 60.13 & Exon 8 & \multirow{2}{*}{$151 b p$} & \multirow{2}{*}{ X54001 } \\
\hline & RP: tggaaactgttggggagaag & $20 b p$ & 60.08 & Exon 10 & & \\
\hline \multirow{2}{*}{$I L-6$} & FP: aaggtgatgccacctcagac & $20 b p$ & 60.12 & Exon 2 & \multirow{2}{*}{$151 \mathrm{bp}$} & \multirow{2}{*}{ M86722 } \\
\hline & RP: tctgccagtacctccttgct & $20 \mathrm{bp}$ & 60.01 & Exon 3 & & \\
\hline \multirow{2}{*}{ IL 10} & FP:tgatggggaggatatcaagg & $20 b p$ & 59.70 & Exon 4 & \multirow{2}{*}{$150 \mathrm{bp}$} & \multirow{2}{*}{ NM_214041 } \\
\hline & RP: tggagcttgctaaaggcact & $20 b p$ & 60.15 & Exon 5 & & \\
\hline \multirow{2}{*}{$\beta$-actin } & FP:ggatgcagaaggagatcacg & $20 b p$ & 60.77 & Exon 4 & \multirow{2}{*}{$130 \mathrm{bp}$} & \multirow{2}{*}{ U07786 } \\
\hline & RP: atctgctggaaggtggacag & $20 b p$ & 60.26 & Exon 5 & & \\
\hline
\end{tabular}

${ }^{1}$ Primers for the porcine TNF-a, IL-6, IL-10, and $\beta$-actin (the housekeeping gene) were designed with Primer 3 (http://frodo.wi.mit.edu).

\section{Calculations and statistical analyses}

The ratio of the expression of the target cytokine genes relative to the housekeeping gene $\beta$-actin was calculated (Kelta et al. 2004, Lackeyram et al. 2010) as:

$$
\mathrm{R}=2^{-\mathrm{Ct} \text { (target }- \text { housekeeping) }}
$$

where $\mathrm{R}$ is the relative expression ratio value of the target cytokine genes; and $\mathrm{Ct}$ is the cycle number at the threshold at which the target cytokine genes and the housekeeping gene $\beta$-actin are amplified beyond the of 30 fluorescence units. We normally set 45 cycles as the maximal cycle number, unless for a target gene with a very low expression level, when we observed a trend to reach the threshold during 45 cycles we would extend the cycle number to 50 or more. Optimal real-time PCR efficiencies were acquired by amplification of dilution series of RNA according to the equation $10^{(-1 / \text { slope })}$ and were consistent between each of the target cytokine genes and the housekeeping gene $\beta$-actin (Lackeyram et al. 2010).

Differences in our reported endpoints between the control and the DSS groups were compared by the analysis of variance (ANOVA). The ANOVA was conducted by using the PROC MIXED model of SAS (SAS Institute, Cary, NC, USA). Homogeneity of variances was examined and confirmed by the Levene's test for the endpoints, including, histology measurements, cytokine concentrations and cytokine mRNA abundances, by using SAS. Related linear regression analyses were conducted by using the Fig.P program (Fig.P, 1993, Biosoft, Cambridge, UK). Comparison of the simple 
linear regression slopes between the control and DSS groups associated with the in vivo upper gut permeability measurements was conducted by using the pooled $t$-test (Byrkit et al. 1987). Where appropriate, data are presented as means \pm SE. $p$ values $<0.05$ were considered significant.

\section{Results}

\section{Growth performance}

The DSS and the control groups of piglets had a similar $(\mathrm{p}>0.05)$ initial BW at the beginning of the study (Table 2). Both the DSS and the control groups of piglets also consumed a similar ( $p>0.05)$ amount of the milk replacer over the course of the experimental period. Despite this, the DSS group had lower $(p<0.05)$ average daily $\mathrm{BW}$ gain and gain to food ratio than the control group (Table 2). Furthermore, piglets receiving the DSS treatment were all associated with severe diarrhea.

\section{Changes in morphological and histopathological endpoints}

Histological analyses of the proximal jejunal cross-sections showed decreases $(p<0.05)$ in the villous height and increases $(\mathrm{p}<0.05)$ in the crypt depths and the smooth muscle thickness in the DSS group compared with the control group (Table 3; Fig. 1A and 1B). The calculated villous height to crypt depth ratio was lower $(p<0.05)$ in the DSS group in comparison with the control group. In colon, a decrease $(\mathrm{p}<0.05)$ in the entire mucosal thickness and an increase $(p<0.05)$ in the smooth muscle thickness were observed in the DSS group compared with the control group (Table 3; Fig. 1C and 1D). Quantitative histopathological grading of inflammation in the jejunum and the colon has been summarized in Table 4 and these data collectively indicate that DSS treatment resulted in 12 fold greater $(\mathrm{p}<0.05)$ inflammation severity scoring in the colon than in the jejunum.

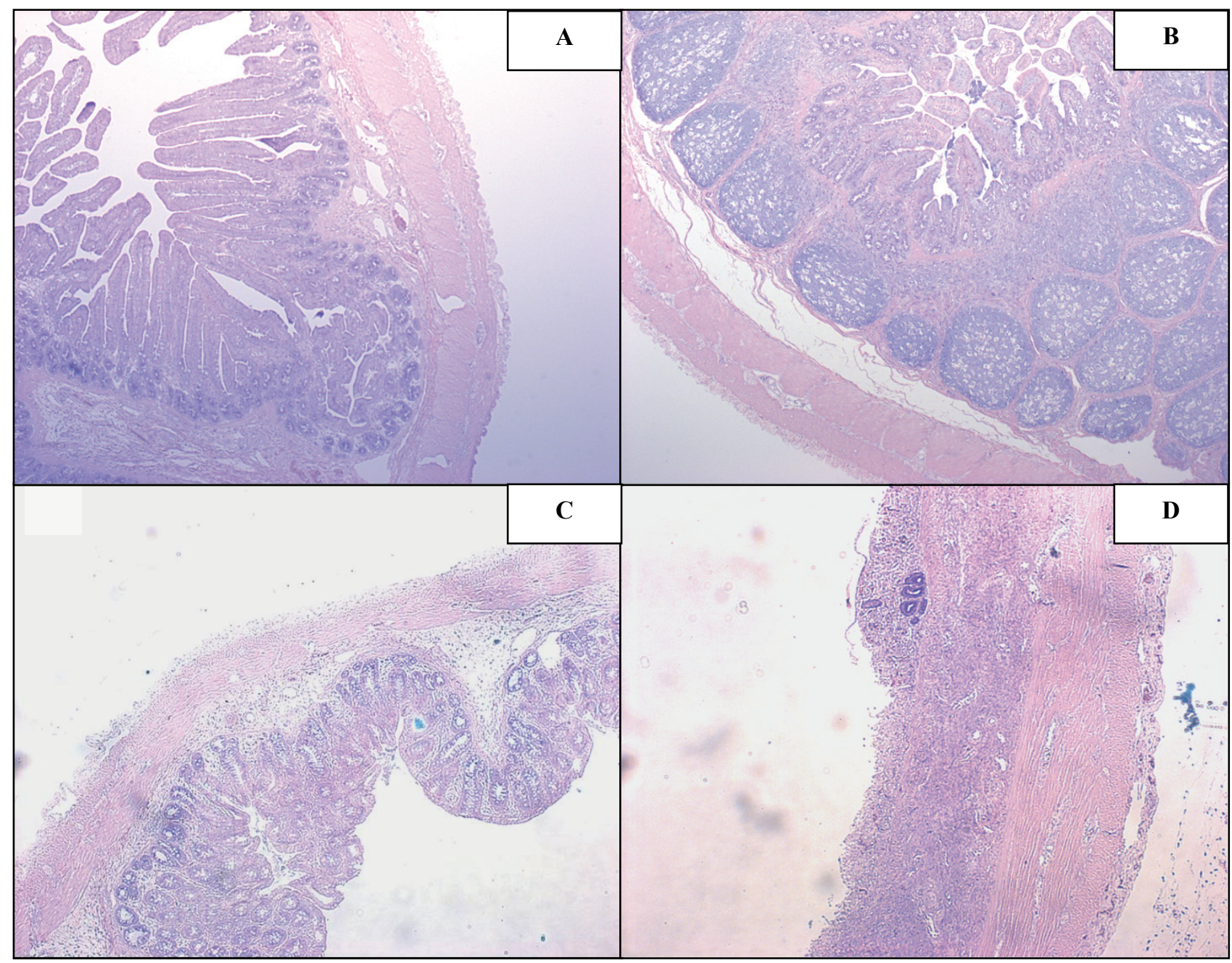

Fig. 1. Pictograph - $10 \mathrm{X}$ magnification of haematoxylin and eosin stained cross sections of intestinal tissues in control and DSS-treated young pigs fed a milk replacer. (A) Proximal jejunum of control piglets. (B) Proximal jejunum of DSS-treated piglets. (C) Colon of control piglets. (D) Colon of DSS-treated piglets. 
Table 2. Comparison of growth performance of control and DSS-treated young pigs fed a milk replacer. ${ }^{1}$

\begin{tabular}{lccc}
\hline Items & Control & DSS & p values \\
\hline Initial BW, $\mathrm{kg}$ & $3.20 \pm 0.18$ & $3.39 \pm 0.04$ & 0.355 \\
Final BW, $\mathrm{kg}$ & $4.90 \pm 0.06^{\mathrm{a}}$ & $4.55 \pm 0.08^{\mathrm{b}}$ & 0.025 \\
Average daily gain, $\mathrm{g} / \mathrm{d}$ & $170.40 \pm 9.17^{\mathrm{a}}$ & $116.36 \pm 16.18^{\mathrm{b}}$ & 0.014 \\
Average formula intake, $\mathrm{ml} / \mathrm{d}$ & $1165.3 \pm 22.20$ & $1216.90 \pm 29.70$ & 0.27 \\
Gain to feed ratio, $\mathrm{g} / \mathrm{ml}$ & $0.15 \pm 0.01^{\mathrm{a}}$ & $0.09 \pm 0.01^{\mathrm{b}}$ & 0.012 \\
\hline
\end{tabular}

${ }^{1}$ Values are means $\pm S E M, n=6$, control group; $n=5$, DSS group. ${ }^{a, b}$ Values in the same row not sharing a superscript letter are different, $\mathrm{p}<0.05$.

Table 3. Comparison of jejunal and colonic morphological endpoints in control and DSS-treated young pigs fed a milk replacer. ${ }^{1}$

\begin{tabular}{lccc}
\hline Items & Control & DSS & p values \\
\hline Proximal jejunum & & & 0.001 \\
Villous height, $\mu \mathrm{m}$ & $448.56 \pm 7.45^{\mathrm{a}}$ & $257.04 \pm 10.53^{\mathrm{b}}$ & 0.002 \\
Crypt depth, $\mu \mathrm{m}$ & $125.09 \pm 2.40^{\mathrm{a}}$ & $168.57 \pm 5.78^{\mathrm{b}}$ & 0.002 \\
Villous to crypt ratio & $3.87 \pm 0.09^{\mathrm{a}}$ & $1.39 \pm 0.07^{\mathrm{b}}$ & 0.001 \\
Muscle thickness, $\mu \mathrm{m}$ & $228.82 \pm 2.42^{\mathrm{a}}$ & $453.58 \pm 15.50^{\mathrm{b}}$ & \\
Colon & & & 0.001 \\
Mucosal thickness, $\mu \mathrm{m}$ & & $346.23 \pm 11.35^{\mathrm{b}}$ & 0.008 \\
Muscle thickness, $\mu \mathrm{m}$ & $641.06 \pm 20.45^{\mathrm{a}}$ & $398.70 \pm 26.92^{\mathrm{b}}$ & \\
\hline
\end{tabular}

${ }^{1}$ Values are means $\pm S E M, n=6$, control group; $n=5$, DSS group. ${ }^{a, b}$ Values in the same row not sharing a superscript letter are different, $p<0.05$.

Table 4. Comparison of histopathological grading of colonic and jejunal inflammation occurrence in control and DSS-treated young pigs fed a milk replacer. ${ }^{1}$

\begin{tabular}{lccc}
\hline Feature graded $^{2}$ & Control & DSS & p values \\
\hline Proximal Jejunum & & & 0.001 \\
Inflammation & $0.06 \pm 0.01^{\mathrm{a}}$ & $1.53 \pm 0.002^{\mathrm{b}}$ & 0.001 \\
Extent & $0.06 \pm 0.01^{\mathrm{a}}$ & $1.07 \pm 0.02^{\mathrm{b}}$ & 0.001 \\
Regeneration & $0.00^{\mathrm{a}}$ & $1.02 \pm 0.001^{\mathrm{b}}$ & 0.001 \\
Crypt damage & $0.00^{\mathrm{a}}$ & $0.40 \pm 0.04^{\mathrm{b}}$ & 0.001 \\
Total Score & $0.11 \pm 0.01^{\mathrm{a}}$ & $4.0 \pm 0.05^{\mathrm{b}}$ & 0.001 \\
Large Intestine & & & 0.001 \\
Inflammation & $0.09 \pm 0.02^{\mathrm{a}}$ & $10.67 \pm 0.17^{\mathrm{b}}$ & 0.001 \\
Extent & $0.09 \pm 0.02^{\mathrm{a}}$ & $10.67 \pm 0.17^{\mathrm{b}}$ & 0.001 \\
Regeneration & $0.00^{\mathrm{a}}$ & $14.13 \pm 0.23^{\mathrm{b}}$ & 0.001 \\
Crypt damage & $0.00^{\mathrm{a}}$ & $15.16 \pm 0.24^{\mathrm{b}}$ & $50.64 \pm 0.79^{\mathrm{b}}$ \\
Total Score & $0.19 \pm 0.04^{\mathrm{a}}$ & & \\
\hline
\end{tabular}

${ }^{1}$ Values are means \pm SEM, $n=6$, control group; $n=5$, DSS group. ${ }^{2}$ Quantitative histological grading of intestinal colitis occurrence was adopted from a previous study (Dieleman et al. 1998). ${ }^{a}, \mathrm{~b}$ Values in the same row not sharing a superscript letter are different, $\mathrm{p}<0.05$. 


\section{In vivo upper gut permeability}

There were linear relationships $(p<0.05)$ between plasma D-mannitol concentrations and post-injection time within 70 min of a bolus ig injection of $0.6 \mathrm{~g} \mathrm{D}$-mannitol $/ \mathrm{kg} \mathrm{BW}$ in both the DSS and the control groups (Fig. 2). The slopes of these linear relationships represent the increase in plasma D-mannitol concentration per min in the piglets in both the DSS and the control groups, and are used as an indicator of in vivo upper gut permeability. The estimated indicator value (parameter estimates $\pm \mathrm{SE}$ ) for the in vivo upper gut permeability was 27.4 fold higher $(p<0.05)$ in the DSS-treated piglets (DSS, $0.1389 \pm 0.0130$ vs. control, $0.0049 \pm 0.0014 \mu \mathrm{mol}$ D-mannitol per $\mathrm{ml}$ plasma $/ \mathrm{min}$ ) compared with the control piglets.

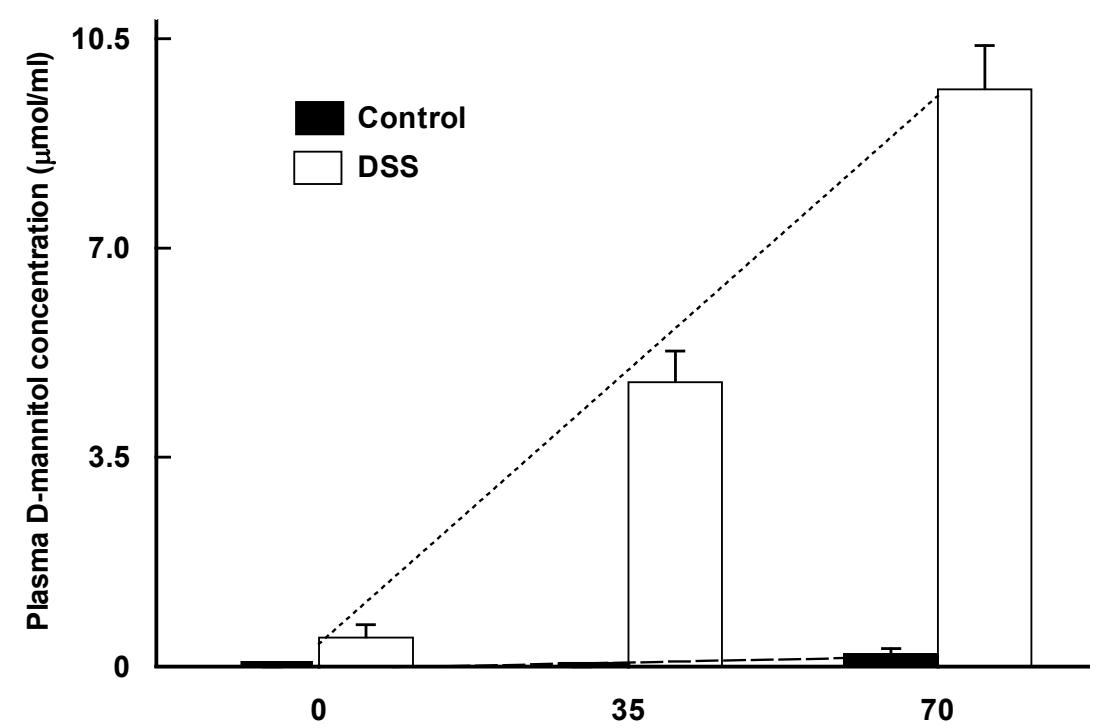

Time of the post-intragastric infusion ( $\mathrm{min}$ )
Fig. 2. Linear relationships between plasma D-mannitol concentration $(\mu \mathrm{mol} / \mathrm{ml})$ and the time ( $\mathrm{min}$ ) of post-ig infusion of D-mannitol in the control compared with DSS-treated young pigs fed a milk replacer. Values represent mean $\pm S E, n=6$, control; $n=5$, DSS group, for each of the marked time points. For the control group, $y=0.0049( \pm 0.0014) * x, r^{2}=0.28, n=36$; for the DSS group, $y=0.1389( \pm 0.0130) * x$, $r^{2}=0.8022, \quad n=30 ; \quad p<0.05$ for all the parameter estimates. Differences in the slopes of the linear relationships were observed between the control and the DSS groups, $\mathrm{p}=0.001$.

\section{Cytokine levels and tissue cytokine mRNA abundances}

When expressed as $\mathrm{pg} / \mathrm{g}$ fresh tissue, IL-10 concentration was reduced $(\mathrm{p}<0.05)$ by 2.4 fold in the colon (DSS, $50.2 \pm 4.4$ vs. control, 169.6 \pm 6.4 ; $\mathrm{p}=0.0008$ ) and by $15 \%$ in the jejunum (DSS, $190.4 \pm 4.8$ vs. control, $224.8 \pm 6.8 ; \mathrm{p}=0.0470$ ) in the DSS group, respectively, compared with the control group. When expressed as $\mathrm{pg} / \mathrm{mg}$ extractable tissue protein for removal of the potentially differential water content effect, IL-10 concentration was also considerably decreased $(\mathrm{p}<0.05)$ in the colon of the DSS group; however, IL-10 concentration was not significantly affected in the jejunum of the DSS group compared with the control group (Fig. 3). Furthermore, when expressed as pg/ml, circulating plasma IL-10 concentration was reduced $(\mathrm{p}<0.05)$ by 1.5 fold in the DSS group (DSS, $110.4 \pm 12.6$ vs. control, 273.8 $\pm 21.7 ; \mathrm{p}=0.0040$ ) compared with the control group. When expressed as $\mathrm{pg} / \mathrm{mg}$ extractable protein, circulating plasma IL-10 concentration was still decreased $(p<0.05)$ in the DSS group compared with the control group (Fig. 3). Real time RT-PCR analyses for the cytokine gene expressions revealed that colonic IL-10
mRNA abundance was decreased to be undetectable, and there was not a trend to reach the threshold even after 45 cycles in the DSS group, while colonic IL-10 mRNA was abundantly expressed in the control group (Table 5). On the contrary, jejunal IL-10 mRNA abundance was 14 fold higher $(p<0.05)$ in the DSS group than in the control group (Table 5).

When expressed as $\mathrm{pg} / \mathrm{mg}$ extractable tissue protein for removal of the potentially differential water content effect, the DSS group had higher concentrations $(p<0.05)$ of both TNF- $\alpha$ and IL- 6 cytokines in the jejunal and colonic tissues compared with the control group (Fig. 3). Furthermore, TNF- $\alpha$ and IL-6 cytokine concentrations ( $\mathrm{pg} / \mathrm{mg}$ extractable tissue protein) were 2.9 and 5.4 fold higher $(\mathrm{p}<0.05)$ in the colon than in the jejunum within the DSS group. However, no differences $(\mathrm{p}>0.05)$ in TNF- $\alpha$ and IL-6 cytokine concentrations were observed between the colon and the proximal jejunum within the control group, when these were expressed as $\mathrm{pg} / \mathrm{mg}$ extractable tissue protein. In addition, there were higher $(\mathrm{p}<0.05)$ circulating plasma TNF- $\alpha$ and IL-6 cytokine concentrations (pg/mg plasma protein) in 
the DSS group than in the control group (Fig. 4). Real time RT-PCR analyses for the cytokine gene expressions revealed higher $(\mathrm{p}<0.05)$ mRNA abundances of TNF- $\alpha$ and IL-6 in both the jejunal and the colonic tissues in the DSS group compared with the control group (Table 5).

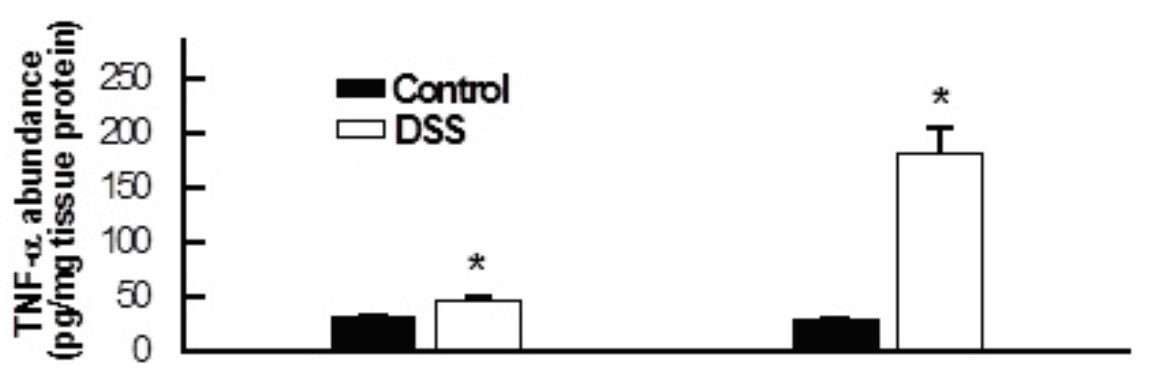

Fig. 3. Concentrations ( $\mathrm{pg} / \mathrm{mg}$ protein) of TNF-a (upper panel), IL-6 (middle panel) and IL-10 (lower panel) analyzed by ELISA in the jejunum and colon of control and DSS-treated young pigs fed a liquid formula. Values are means \pm SEM, $\mathrm{n}=6$, control; $\mathrm{n}=5$, DSS group. *Indicate differences from control, $\mathrm{p}<0.05$.
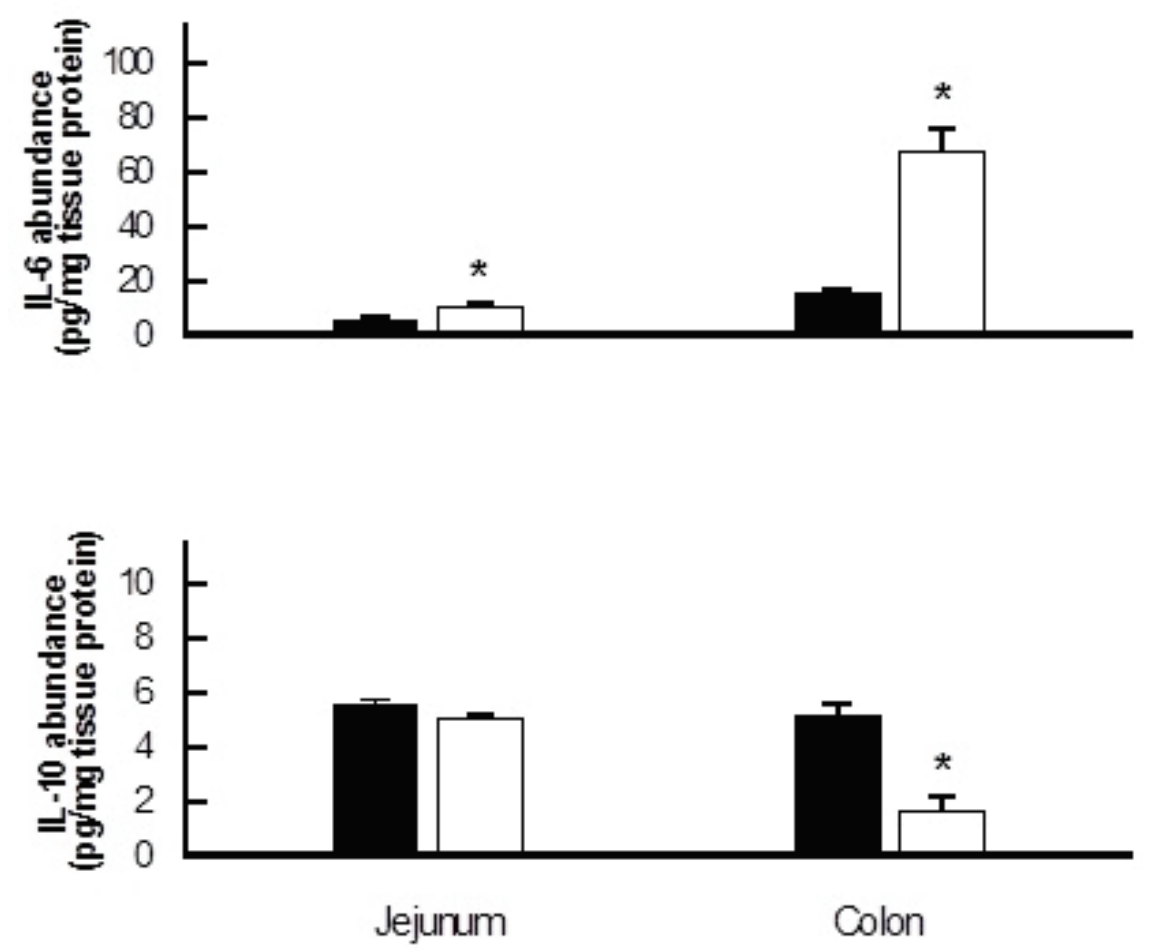

\section{Discussion}

Although the exact etiology of IBD is unknown, the pathology has been associated with relapsing intestinal inflammation (Sartor 1997, Fiocchi 1998) linking to increased epithelial permeability (Podolsky 2002), psychological stress (Mawdsley and Rampton 2007), environmental factors such as smoking (Somerville et al. 1984), and diets and nutrition (Ainley et al. 1991). Thus, biological mechanisms as well as preventive and therapeutic strategies need to be further investigated. Intestinal inflammation is the hallmark of IBD and a number of experimental models have been developed to investigate roles of innate immunity, adaptive immune system and regulatory immune mechanisms playing in the pathogenesis of IBD through cytokines (Papadakis and Targan 2000, Strober et al. 2002, Elson et al. 2005). Earlier studies showed that administration of DSS induced colonic mucosal immune responses due to development of pathogenic microflora and phagocytosis of DSS by macrophages in the mucosa (Okayasu et al. 1990). Both acute and chronic ulcerative colitis, as induced by DSS, were investigated in several animal species, including mice (Okayasu et al. 1990, Dieleman et al. 1998), rats (Tsune et al. 2003), guinea pigs (Iwanaga et al. 1994) and more recently with piglets (Mackenzie et al. 2003, Bassaganya-Riera and Hontecillas 2006, Kim et al. 2009, Young et al. 2010). 
A convenient route of DSS delivery for inducing intestinal inflammation in smaller laboratory animals such as mice, rats and guinea pigs is through drinking water. However, pigs are sensitive to the flavor of their diets and water, so ig infusion of DSS via a catheter is effective when using the pig model (Mackenzie et al. 2003, Bassaganya-Riera and Hontecillas 2006, Kim et al. 2009, Young et al. 2010). Thus, DSS has been widely used to induce acute and chronic bowel inflammation associated ulcerative colitis in animal models.
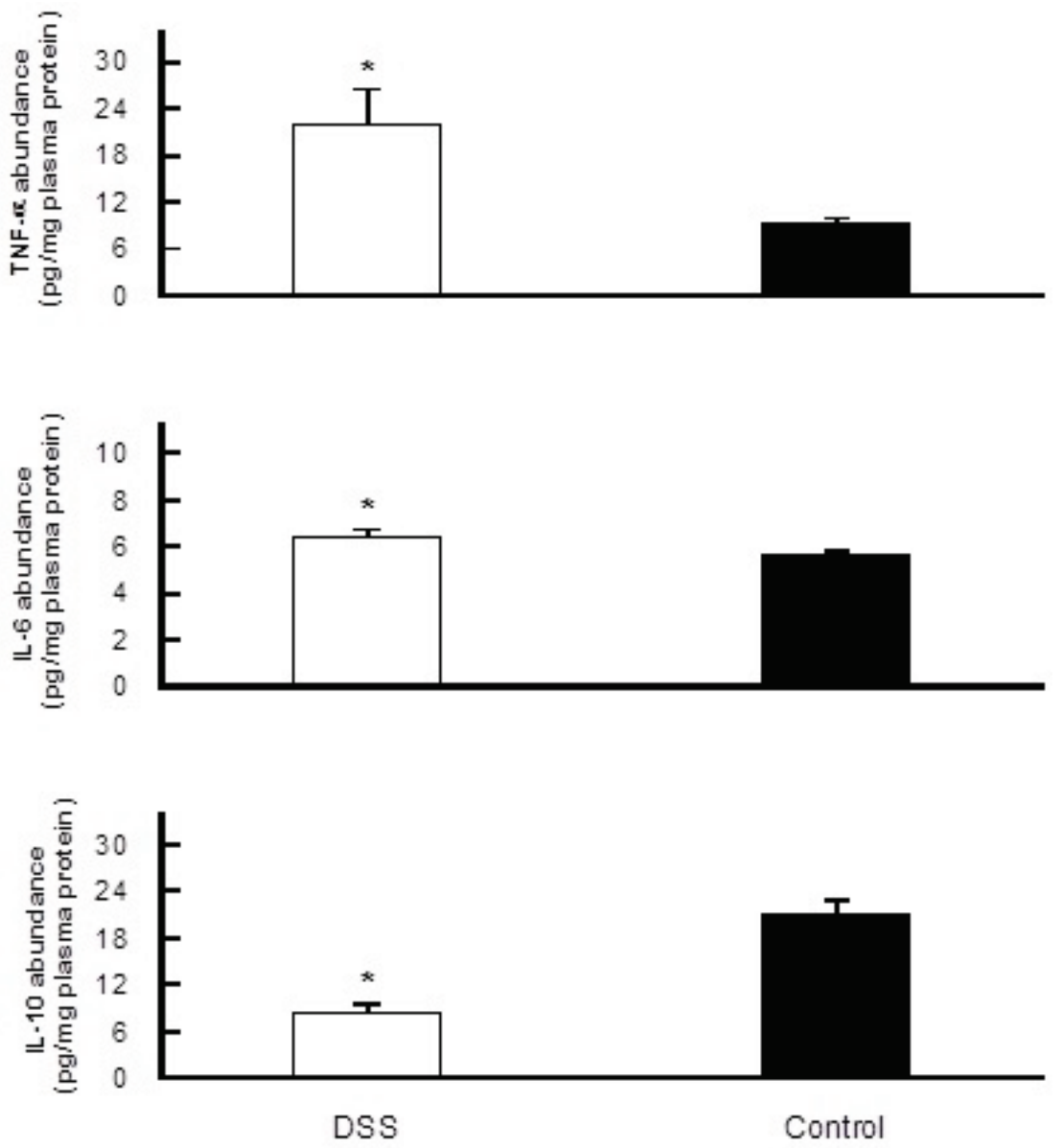

Fig. 4. Concentrations ( $\mathrm{pg} / \mathrm{mg}$ protein) of TNF-a (upper panel), IL-6 (middle panel) and IL-10 (lower panel) peptides ( $\mathrm{pg} / \mathrm{mg}$ protein) analyzed by ELISA in the plasma of control and DSS-treated young pigs fed a liquid formula. Values are means \pm SEM, $n=6$, control; $n=5$, DSS group. *Indicate differences from control, $\mathrm{p}<0.05$.

Table 5. Comparison of relative mRNA expressions ${ }^{1}$ of TNF-a, IL-6 and IL-10 in the proximal jejunum and colon measured by real time $\mathrm{RT}-\mathrm{PCR}$ in control and DSS-treated young pigs fed a milk replacer.

\begin{tabular}{lccc}
\hline Items & Control & DSS & $p$ values \\
\hline Proximal jejunum & & & 0.001 \\
TNF- $\alpha$ & $0.004 \pm 0.0002^{\mathrm{a}}$ & $5.367 \pm 0.289^{\mathrm{b}}$ & 0.001 \\
$I L-6$ & $0.006 \pm 0.0005^{\mathrm{a}}$ & $0.5753 \pm 0.018^{\mathrm{b}}$ & 0.001 \\
$I L-10$ & $2.195 \pm 0.244^{\mathrm{a}}$ & $33.350 \pm 7.080^{\mathrm{b}}$ & 0.001 \\
Colon & & & 0.001 \\
TNF- $\alpha$ & $0.011 \pm 0.002^{\mathrm{a}}$ & $1.210 \pm 0.510^{\mathrm{b}}$ & -
\end{tabular}

${ }^{1}$ Values are means \pm SEM, $n=6$, control group; $n=5$, DSS group. $\beta$-actin was used as the housekeeping gene for data normalization. ${ }^{2}$ UD: undetectable by real time RT-PCR analysis. ${ }^{a, b}$ Values in the same row not sharing a superscript letter are different, $p<0.05$. 
Acute bowel inflammation associated with acute ulcerative colitis is mediated by innate immunity through rapid responses of cytokine and IgA secretions from immune cells localized in the colon, including intraepithelial lymphocytes, dendritic cells, and lymphocytes and macrophages in Peyer's patches, lamina propria and mesentery lymphoid nodes (Strober et al. 2002, Elson et al. 2005). Increased colonic apical expression of toll-like receptor-4 (TLR-4), as mediated by lipopolysaccharide endotoxin, is shown to induce innate immunity and DSS-induced acute ulcerative colitis (Fukata et al. 2005, Fukata and Abreu 2008). Because of absence of adaptive immunity responses, a DSS-induced acute ulcerative colitis model would not suitable for studying cellular and molecular events and immunological mechanisms involved in developing chronic bowel inflammation (Grisham 2008). Therefore, a DSS-induced acute ulcerative colitis model is only particularly useful for testing preventive strategies and for understanding cellular events and molecular mechanisms associated with epithelial adaptation during the onset of bowel inflammation.

Chronic bowel inflammation associated with chronic bowel diseases such as chronic ulcerative colitis in the colon is mediated by adaptive immunity and regulatory immune mechanisms through recruiting effector $\mathrm{T}$ and $\mathrm{B}$ immune cells from the primary immune organs (Strober et al. 2002, Elson et al. 2005). Elevated expression of pro-inflammatory cytokines, such as tumor necrosis factor alpha (TNF- $\alpha$ ) and interleukin-6 (IL-6), occurs under both acute and chronic bowel inflammation (Papadakis and Targan 2000). Thus, profiling pro-inflammatory gene expression alone is not suitable to serve as a benchmark for evaluating chronic bowel inflammation. The anti-inflammatory role of IL-10 was classically demonstrated in the IL-10-deficient mouse study (Kühn et al. 1993). Colonic expression of anti-inflammatory cytokine IL-10 is uniquely different between the onset of acute bowel inflammation and the progression of chronic bowel inflammation. Colonic IL-10 gene expression, as marked by IL-10 mRNA abundances, was enhanced under acute bowel inflammation via innate immunity (Egger et al. 2000, Braat et al. 2003, Kim et al. 2009, Young et al. 2010). However, the IL-10 level was shown to be very low in chronic inflamed mucosal tissues contributed primarily by recruited effector $\mathrm{T}$ cells and macrophages via adaptive immunity and regulatory immune mechanisms (Autschbach et al. 1998, Gasche et al. 2000). Therefore, decreases in IL-10 concentration and IL-10 mRNA abundance are recognized biomarkers for the status of chronic bowel inflammation.

The primary objective of this study was to investigate if chronic colonic inflammation responses associated with chronic ulcerative colitis in the colon of young pigs could be induced through administration of an effective dose of DSS for a time period of 10 days through comparatively profiling IL-10 gene expression in both the colon and the small intestine. We are interested in the development of a DSS-induced chronic ulcerative colitis model in young pigs through profiling cytokine gene expression for the following reasons. Chronic inflammatory bowel diseases do occur in infants and children (Kappelman and Grand 2008, Kelsen and Baldassano 2008). A young pig based chronic ulcerative colitis model will allow studies of IBD with implications to both children and adults. Although active immunity in piglets is not fully developed to its peak maturity until 7 weeks of age (Fan 2003), it is rapidly developing in young pigs. Thus, DSS challenge can theoretically provoke both innate and adaptive immunity and chronic bowel inflammation in young pigs. Furthermore, pigs are now widely recognized as a relevant animal model for studying human gastrointestinal physiology and nutrition and a young pig based chronic ulcerative colitis model will allow the use of a much smaller quantity of bioactive compounds at their early stage of development for therapeutic oriented research.

The 2.4 fold dramatic reduction of the IL-10 concentration (Fig. 3) and declining to the undetectable level (Table 5) of the relative IL-10 mRNA abundance in the colon of the DSS group from this study supported our original research hypothesis that chronic colonic inflammation occurred in the young pigs following the 10-day period of the DSS administration. These results are in line with reported human clinic studies in showing that the colonic IL-10 level was declined to a very low level in chronic inflamed mucosa contributed primarily by recruited effector $\mathrm{T}$ cells and macrophages via adaptive immunity (Autschbach et al. 1998, Gasche et al. 2000). Significant decreases in circulating plasma levels of IL-10 were also observed in the DSS group in this study (Fig. 4). However, blood circulation of systemic levels of IL-10 was not always necessarily shown to be linked to status of chronic bowel inflammation (Braat et al. 2003). Gut mucosal IL-10 is known to be contributed by many cell types, including $\mathrm{T}$ cells, mast cells, epithelial cells, macrophages and dendritic cells 
(Unutmaz and Pulendran 2009). It has been further revealed that lamina propria-recruited macrophages are the major cellular contributor to the mucosal IL-10, and interstitial IL-10, acted, in a paracrine manner, in promoting regulatory $\mathrm{T}$ cells to express transcriptional factor Foxp3 for suppressing autoimmune responses (Murai et al. 2009, Unutmaz and Pulendran 2009). Considering that colonic monocytes such as macrophages only represented a very small fraction of cell populations in the colonic mucosa, expression of total IL-10 mRNA abundance relative to the housekeeping gene $\beta$-actin in the homogenized colonic mucosa obtained for the DSS group might have been dramatically reduced to be undetectable in this study (Table 5). On the other hand, the jejunal IL-10 mRNA relative abundance was drastically enhanced, in contrast to, the colon within the DSS group in this study (Table 5). These observations have two implications. Firstly, the DSS administration did not cause chronic inflammation to the jejunal mucosa in the young pigs in this study. Secondly, adaptive immunity and regulatory immune mechanisms responded differentially to the jejunal and colonic mucosal tissues under the DSS-induced chronic ulcerative colitis in the colon of young pigs in this study. Under this context, it should be pointed out that only acute inflammation and acute ulcerative colitis in the colon were induced upon administration of the same dose of DSS $(1.25 \mathrm{~g} / \mathrm{kg} \mathrm{BW})$ for 5 days, as indicated by the enhanced colonic IL-10 mRNA abundances in our previous studies with young pigs (Kim et al. 2009, Young et al. 2012). Therefore, it can be concluded that administration of DSS $(1.25 \mathrm{~g} / \mathrm{kg}$ $\mathrm{BW}$ ) for 10 days was effective in inducing a marked reduction in the colonic concentration and mRNA abundance of IL-10 and the development of chronic inflammation associated with chronic ulcerative colitis in the colon of young pigs.

It has been well established that expressions of the pro-inflammatory cytokines TNF- $\alpha$ and IL-6 are recognized major biomarkers of intestinal inflammation (Braegger et al. 1992, Rugtveit et al. 1997, Mudter and Neurath 2007). Significant increases in both TNF- $\alpha$ and IL-6 cytokine concentrations and relative mRNA abundances in the jejunal and colonic tissues were observed in the DSS group when compared with the control group (Table 5; Fig. 3). Furthermore, TNF- $\alpha$ and IL-6 concentrations in circulating blood were higher in the DSS group than in the control group (Fig. 4). These significant intestinal local and systemic responses in the TNF- $\alpha$ and IL-6 concentrations could have further attributed to either a decreased protection of the small intestine to enteral antigens and/or the angiogenic responses involved in tissue repair (Chidlow et al. 2007), further suggesting the contribution of adaptive immunity responses in this study. Furthermore, within the DSS treatment group, the TNF- $\alpha$ and IL-6 cytokine levels were much higher in the colonic than in the jejunal tissue (Fig. 3), suggesting that the DSS administration caused much more severe inflammatory responses in the colon. These results were consistent with the histopathological grading of the proximal jejunum and colon, suggesting that the DSS treatment resulted in considerable transmural inflammatory damage in the colon (Table 4). Our morphological data in Table 3 showed that the DSS administration and the associated inflammation caused considerable villous atrophy, crypt hyperplasia and stimulated smooth muscle growth, which is not uncommon to the injured gut. Both TNF- $\alpha$ and IL-6 have been shown to reduce mucosal hypertrophic growth and cell maturation by inhibiting the mammalian target of rapamycin-signaling pathway mediated cellular protein synthesis (Yang et al. 2008). In addition, both TNF- $\alpha$ and IL-6, are known to affect crypt cell proliferation and apoptosis, thus contributing to hyperplasic crypt cellular growth (Seidelin 2004). This is compounded by the ability of IL-6 to recruit angiogenic adhesion molecules that contribute to classic IBD mucosal lesions when unregulated during inflammation (Romano et al. 1997, Ito et al. 2002). Hence, our data further suggested that administration of DSS at $1.25 \mathrm{~g} / \mathrm{kg}$ BW for 10 days resulted in significant bowel inflammation with a particular severity in the colon, demonstrating chronic ulcerative colitis in the colon of young pigs in this study by taking together of the IL-10 expression data.

It has been well demonstrated that abnormal upper gut permeability, especially in the stomach and the small intestinal region, predisposes the gut mucosal local immune system and the body primary immune organs to interact with antigens originated and presented from the gut lumen, leading to contribution of adaptive immune responses to the pathogenesis of chronic bowel inflammation and IBD (Meddings 2008, Arrieta et al. 2009, Su et al. 2009). The dramatic 27.4 fold increase (Fig. 2) in the rate of plasma D-mannitol concentration rising in the DSS group highlights the compromised permeability of the stomach and the small intestine due to DSS administration in the young pigs in this study. It should be pointed out that D-mannitol used in this study is a transcellular permeability marker. Nevertheless, our 
in vivo stomach-small intestine-specific permeability data supported the notion of abrogation of the upper bowel barrier function is a pre-requisite for the occurrence of chronic bowel inflammation and the development of IBD (Meddings 2008, Arrieta et al. 2009, Su et al. 2009). Therefore, compromised upper gut permeability due to the DSS administration contributed to the development of the acute inflammation in the jejunum and the chronic inflammation in association with chronic ulcerative colitis in the colon of the young pigs in this study.

Interestingly, feed intake was not significantly reduced in the DSS-infused young pigs, even though severe intestinal inflammation was present. This result is, in contrast to, the previous observations of a reduced food intake associated with IBD due to cytokine-induced anorexia and food avoidance (Hoshino et al. 1991, Rigaud et al. 1994). Differences in experimental conditions such as age or species of test animals or human subjects and the duration of inflammation might have affected pro-inflammatory cytokine levels in the blood circulation and food intake responses between the studies. The significantly lower BW gain and feed conversion efficiency in the DSS-treated piglets in comparison with the control group observed in this study are typical symptoms of chronic ulcerative colitis (Leenen and Dieleman 2007), and may be explained by several reasons. Firstly, active colitis enhances the whole body energy metabolic rate (Klein et al. 1988, Azcue et al. 1997). Secondly, the small intestinal villous atrophy associated with IBD demonstrated by DSS challenge in this study might have resulted in a degree of compromised final phase nutrient digestion in the small intestine (Lackeyram et al. 2012), which could exacerbate IBD symptoms in the large intestine such as food intolerance (Atkinson et al. 2004, Rigaud et al. 1994), bacterial overgrowth and bloating (Pimentel et al. 2000). Thirdly, absorbed amino acids are first-pass utilized by the gut and other visceral organs such as liver in the young pig (Stoll et al. 1998). Under intestinal inflammation, a much larger proportion of the absorbed amino acids are shifted for their local utilization and metabolism in the gut and the other visceral organs, resulting in a much reduced availability of the absorbed amino acids for the peripheral muscle protein synthesis and deposition (Fan et al. 2006). Finally, it has been well documented that bowel inflammation such as IBD alters whole body protein metabolism by reducing protein synthesis and increasing protein degradation in the skeletal muscle, and enhancing amino acid supply to the increased demands of visceral organ protein synthesis (Heys et al. 1992, Farges et al. 2002, Mercier et al. 2002). Therefore, growth rate and efficiency of dietary nutrient utilization were decreased during the chronic bowel inflammation in association with chronic ulcerative colitis in the colon induced by DSS in the young pigs in this study.

In summary, administration of DSS at $1.25 \mathrm{~g} / \mathrm{kg}$ BW for 10 days was effective in inducing a marked reduction in the concentration and mRNA abundance of IL-10 and elevated concentrations and mRNA abundances of TNF- $\alpha$ and IL- 6 in the colon of the young pigs. Taken together, our results suggest that this study regimen represented a time period (i.e. 10 days) in the DSS administration at $1.25 \mathrm{~g} / \mathrm{kg} \mathrm{BW}$ for the development of chronic inflammation in association with chronic ulcerative colitis in the colon of young pigs. Furthermore, we demonstrated that the upper gut permeability was compromised in the young pigs under the chronic inflammation with chronic ulcerative colitis in the colon as induced by DSS. Therefore, this DSS-induction based chronic ulcerative colitis young pig model is useful for studying mechanisms and therapeutic strategies associated with the regulation of IL-10 gene expression in the colon as well as cellular and molecular events responsible for the compromised upper gut permeability under chronic bowel inflammation linked to ulcerative colitis in humans.

\section{Conflict of Interest}

There is no conflict of interest.

\section{Acknowledgements}

Supported by research grants from the Natural Sciences and Engineering Research Council (NSERC) of Canada Discovery Program and the Ontario Ministry of Agriculture, Food and Rural Affairs (OMAFRA) - the University of Guelph Partnership Research Program (to M.Z. Fan).

\section{References}

AINLEY C, CASON J, SLAVIN BM, WOLSTENCROFT RA, THOMPSON RP: The influence of zinc status and malnutrition on immunological function in Crohn's disease. Gastroenterology 100: 1616-1625, 1991. 
ARRIETA MC, MADSEN K, DOYLE J, MEDDINGS J: Reducing small intestinal permeability attenuates colitis in the IL10 gene-deficient mouse. Gut 58: 41-48, 2009.

ATKINSON W, SHELDON TA, SHAATH N, WHORWELL PJ: Food elimination based on IgG antibodies in irritable bowel syndrome: a randomised controlled trial. Gut 53: 1459-1464, 2004.

AUTSCHBACH F, BRAUNSTEIN J, HELMKE B, ZUNA I, SCHÜRMANN G, NIEMIR ZI, WALLICH R, OTTO HF, MEUER SC: In situ expression of interleukin-10 in noninflamed human gut and in inflammatory bowel disease. Am J Pathol 153: 121-130, 1998.

AZCUE M, RASHID M, GRIFFITHS A, PENCHARZ PB: Energy expenditure and body composition in children with Crohn's disease: effect of enteral nutrition and treatment with prednisolone. Gut 41: 203-208, 1997.

BASSAGANYA-RIERA J, HONTECILLAS R: CLA and n-3 PUFA differentially modulate clinical activity and colonic PPAR-responsive gene expression in a pig model of experimental IBD. Clin Nutr 25: 454-465, 2006.

BRAAT H, PEPPELENBOSCH MP, HOMMES DW: Interleukin-10-based therapy for inflammatory bowel disease. Expert Opin Biol Ther 3: 725-731, 2003.

BRAEGGER CP, NICHOLLS S, MURCH SH, MACDONALD TT, STEPHENS S: Tumour necrosis factor alpha in stool as a marker of intestinal inflammation. Lancet 339: 89-91, 1992.

BYRKIT DR, SCHAEFER RL, SKILLINGS JH: Statistics Today: A Comprehensive Introduction. BenjaminCummings Pub Co, Menlo Park, 1987.

CANADIAN COUNCIL ON ANIMAL CARE: Guide to the Care and Use of Experimental Animals. MCWILLIAM A, CROSS B, OLFERT E (eds), Ottawa, 1993.

CHENG H, LEBLOND CP: Origin, differentiation and renewal of the four main epithelial cell types in the mouse small intestine. I. Columnar cell. Am J Anat 141: 461-479, 1974.

CHIDLOW JH, SHUKLA D, GRISHAM MB, KEVIL CG: Pathogenic angiogenesis in IBD and experimental colitis: new ideas and therapeutic avenues. Am J Physiol Gastrointest Liver Physiol 293: G5-G18, 2007.

COHEN SL, MOORE AM, WARD WE: Interleukin-10 knockout mouse: a model for studying bone metabolism during intestinal inflammation. Inflamm Bowel Dis 10: 557-563, 2004.

DIELEMAN LA, PALMEN MJ, AKOL H, BLOEMENA E, PEÑA AS, MEUWISSEN SG, VAN REES EP: Chronic experimental colitis induced by dextran sulphate sodium (DSS) is characterized by Th1 and Th2 cytokines. Clin Exp Immunol 114: 385-391, 1998.

EGGER B, BAJAJ-ELLIOTT M, MACDONALD TT, INGLIN R, EYSSELEIN VE, BÜCHLER MW: Characterisation of acute murine dextran sodium sulphate colitis: cytokine profile and dose dependency. Digestion 62: 240-248, 2000.

ELSON CO, CONG Y, MCCRACKEN VJ, DIMMITT RA, LORENZ RG, WEAVER CT: Experimental models of inflammatory bowel disease reveal innate, adaptive, and regulatory mechanisms of host dialogue with the microbiota. Immunol Rev 206: 260-276, 2005.

FAN MZ: Growth and Ontogeny of the Gastrointestinal Tract. In: The Neonatal Pig: Gastrointestinal Physiology and Nutrition. XU RJ, CRANWELL PD (eds), Nottingham University Press, Nottingham, 2003, pp 31-60.

FAN MZ, CHIBA LI, MATZAT PD, YANG X, YIN YL, MINE Y, STEIN HH: Measuring synthesis rates of nitrogencontaining polymers by using stable isotope tracers. J Anim Sci 84 (Suppl): E79-E93, 2006.

FAN MZ, STOLL B, JIANG R, BURRIN DG: Enterocyte digestive enzyme activity along the crypt-villus and longitudinal axes in the neonatal pig small intestine. J Anim Sci 79: 371-381, 2001.

FARGES MC, BALCERZAK D, FISHER BD, ATTAIX D, BÉCHET D, FERRARA M, BARACOS VE: Increased muscle proteolysis after local trauma mainly reflects macrophage-associated lysosomal proteolysis. $\mathrm{Am}$ J Physiol Endocrinol Metab 282: E326-E335, 2002.

FIOCCHI C: Inflammatory bowel disease: etiology and pathogenesis. Gastroenterology 115: 182-205, 1998.

FUKATA M, ABREU MT: What are toll-like receptors and what role may they have in IBD? Inflamm Bowel Dis 14 (Suppl 2): S90-S92, 2008.

FUKATA M, MICHELSEN KS, ERI R, THOMAS LS, HU B, LUKASEK K, NAST CC, LECHAGO J, XU R, NAIKI Y: Toll-like receptor-4 is required for intestinal response to epithelial injury and limiting bacterial translocation in a murine model of acute colitis. Am J Physiol Gastrointest Liver Physiol 288: G1055-G1065, 2005. 
GASCHE C, BAKOS S, DEJACO C, TILLINGER W, ZAKERI S, REINISCH W: IL-10 secretion and sensitivity in normal human intestine and inflammatory bowel disease. J Clin Immunol 20: 362-370, 2000.

GRAEFE H, GÜTSCHOW B, GEHRING H, DIBBELT L: Sensitive and specific photometric determination of mannitol in human serum. Clin Chem Lab Med 41: 1049-1055, 2003.

GRISHAM MB: Do different animal models of IBD serve different purposes? Inflamm Bowel Dis 14 (Suppl 2): S132-S133, 2008.

HEYS SD, PARK KG, MCNURLAN MA, KEENAN RA, MILLER JD, EREMIN O, GARLICK PJ: Protein synthesis rates in colon and liver: stimulation by gastrointestinal pathologies. Gut 33: 976-981, 1992.

HOSHINO E, PICHARD C, GREENWOOD CE, KUO GC, CAMERON RG, KURIAN R, KEARNS JP, ALLARD JP, JEEJEEBHOY KN: Body composition and metabolic rate in rat during a continuous infusion of cachectin. Am J Physiol 260: E27-E36, 1991.

ITO H, HIROTANI T, YAMAMOTO M, OGAWA H, KISHIMOTO T: Anti-IL-6 receptor monoclonal antibody inhibits leukocyte recruitment and promotes T-cell apoptosis in a murine model of Crohn's disease. J Gastroenterol 37: 56, 2002.

IWANAGA T, HOSHI O, HAN H, FUJITA T: Morphological analysis of acute ulcerative colitis experimentally induced by dextran sulfate sodium in the guinea pig: some possible mechanisms of cecal ulceration. J Gastroenterol 29: 430-438, 1994.

KAPPELMAN MD, GRAND RJ: Does inflammatory bowel disease develop in infants? Inflamm Bowel Dis 14 (Suppl 2): S6-S8, 2008.

KELSEN J, BALDASSANO RN: Inflammatory bowel disease: the difference between children and adults. Inflamm Bowel Dis 14 (Suppl 2): S9-S11, 2008.

KIDDER DE, MANNERS MJ: Digestion in the Pig. Scientechnica, Bristol, UK, 1978.

KIM CJ, KOVACS-NOLAN J, YANG C, ARCHBOLD T, FAN MZ, MINE Y: L-cysteine supplementation attenuates local inflammation and restores gut homeostasis in a porcine model of colitis. Biochim Biophys Acta 1790: 1161-1169, 2009.

KIM CJ, KOVACS-NOLAN JA, YANG C, ARCHBOLD T, FAN MZ, MINE Y: L-Tryptophan exhibits therapeutic function in a porcine model of dextran sodium sulfate (DSS)-induced colitis. J Nutr Biochem 21: 468-475, 2010.

KLETA R, ROMEO E, RISTIC Z, OHURA T, STUART C, ARCOS-BURGOS M, DAVE MH, WAGNER CA, CAMARGO SR, INOUE S, ET AL.: Mutations in SLC6A19, encoding B ${ }^{0}$ AT1, cause Hartnup disorder. Nat Genet 36: 999-1002, 2004.

KLEIN S, MEYERS S, O'SULLIVAN P, BARTON D, LELEIKO N, JANOWITZ HD: The metabolic impact of active ulcerative colitis. Energy expenditure and nitrogen balance. J Clin Gastroenterol 10: 34-40, 1988.

KÜHN R, LÖHLER J, RENNICK D, RAJEWSKY K, MÜLLER W: Interleukin-10-deficient mice develop chronic enterocolitis. Cell 75: 263-274, 1993.

LACKEYRAM D, MINE Y, ARCHBOLD A, FAN MZ: The small intestinal apical hydrolase activities are decreased in the piglet with bowel inflammation induced by dextran sodium sulfate. J Anim Sci 90: 287-289, 2012.

LACKEYRAM D, YANG C, ARCHBOLD T, SWANSON KC, FAN MZ: Early weaning reduces small intestinal alkaline phosphatase expression in pigs. J Nutr 140: 461-468, 2010.

LEENEN $\mathrm{CH}$, DIELEMAN LA: Inulin and oligofructose in chronic inflammatory bowel disease. J Nutr 137 (11 Suppl): 2572S-2575S, 2007.

LONGSTRETH GF, THOMPSON WG, CHEY WD, HOUGHTON LA, MEARIN F, SPILLER RC: Functional bowel disorders. Gastroenterology 130: 1480-1491, 2006.

LUNN PG, NORTHROP CA, NORTHROP AJ: Automated enzymatic assays for the determination of intestinal permeability probes in urine. 2. Mannitol. Clin Chim Acta 183: 163-170, 1989.

MACKENZIE ML, WARREN MR, WYKES LJ: Colitis increases albumin synthesis at the expense of muscle protein synthesis in macronutrient-restricted piglets. $J$ Nutr 133: 1875-1881, 2003.

MAWDSLEY JE, RAMPTON DS: The role of psychological stress in inflammatory bowel disease. Neuroimmunomodulation 13: 327-336, 2007. 
MEDDINGS J: What role does intestinal permeability have in IBD pathogenesis? Inflamm Bowel Dis 14 (Suppl 2): S138-S139, 2008.

MERCIER S, BREUILLÉ D, MOSONI L, OBLED C, PATUREAU MIRAND P: Chronic inflammation alters protein metabolism in several organs of adult rats. J Nutr 132: 1921-1928, 2002.

MUDTER J, NEURATH MF: Il-6 signaling in inflammatory bowel disease: pathophysiological role and clinical relevance. Inflamm Bowel Dis 13: 1016-1023, 2007.

MURAI M, TUROVSKAYA O, KIM G, MADAN R, KARP CL, CHEROUTRE H, KRONENBERG M: Interleukin 10 acts on regulatory $\mathrm{T}$ cells to maintain expression of the transcription factor Foxp3 and suppressive function in mice with colitis. Nat Immunol 10: 1178-1184, 2009.

MURCH SH, LAMKIN VA, SAVAGE MO, WALKER-SMITH JA, MACDONALD TT: Serum concentrations of tumour necrosis factor alpha in childhood chronic inflammatory bowel disease. Gut 32: 913-917, 1991.

OKAYASU I, HATAKEYAMA S, YAMADA M, OHKUSA T, INAGAKI Y, NAKAYA R: A novel method in the induction of reliable experimental acute and chronic ulcerative colitis in mice. Gastroenterology 98: 694-702, 1990.

PAPADAKIS KA, TARGAN SR: Role of cytokines in the pathogenesis of inflammatory bowel disease. Ann Rev Med 51: 289-298, 2000.

PIMENTEL M, CHOW EJ, LIN HC: Eradication of small intestinal bacterial overgrowth reduces symptoms of irritable bowel syndrome. Am J Gastroenterol 95: 3503-3506, 2000.

PODOLSKY DK: Inflammatory bowel disease. $N$ Engl J Med 347: 417-429, 2002.

RIDEOUT TC, YUAN Z, BAKOVIC M, LIU Q, LI RK, MINE Y, FAN MZ: Guar gum consumption increases hepatic nuclear SREBP2 and LDL receptor expression in pigs fed an atherogenic diet. J Nutr 137: 568-572, 2007.

RIGAUD D, ANGEL LA, CERF M, CARDUNER MJ, MELCHIOR JC, SAUTIER C, RENÉ E, APFELBAUM M, MIGNON M: Mechanisms of decreased food intake during weight loss in adult Crohn's disease patients without obvious malabsorption. Am J Clin Nutr 60: 775-781, 1994.

ROMANO M, SIRONI M, TONIATTI C, POLENTARUTTI N, FRUSCELLA P, GHEZZI P, FAGGIONI R, LUINI W, VAN HINSBERGH V, SOZZANI S, BUSSOLINO F, POLI V, CILIBERTO G, MANTOVANI A: Role of IL-6 and its soluble receptor in induction of chemokines and leukocyte recruitment. Immunity 6: 315-325, 1997.

RUGTVEIT J, NILSEN EM, BAKKA A, CARLSEN H, BRANDTZAEG P, SCOTT H: Cytokine profiles differ in newly recruited and resident subsets of mucosal macrophages from inflammatory bowel disease. Gastroenterology 112: 1493-1505, 1997.

SARTOR RB: Pathogenesis and immune mechanisms of chronic inflammatory bowel diseases Am J Gastroenterol 92 : 5S-11S, 1997.

SÁNCHEZ-FIDALGO S, CÁRDENO A, VILLEGAS I, TALERO E, DE LA LASTRA CA: Dietary supplementation of resveratrol attenuates chronic colonic inflammation in mice. Eur J Pharmacol 633: 78-84, 2010.

SEIDELIN JB: Colonic epithelial cell turnover: possible implications for ulcerative colitis and cancer initiation. Scand J Gastroenterol 39: 20111, 2004.

SNOECK V, HUYGHEBAERT N, COX E, VERMEIRE A, SAUNDERS J, REMON JP, VERSCHOOTEN F, GODDEERIS BM: Gastrointestinal transit time of nondisintegrating radio-opaque pellets in suckling and recently weaned piglets. $J$ Control Release 94: 143-153, 2004.

SOMERVILLE KW, LOGAN RF, EDMOND M, LANGMAN MJ: Smoking and Crohn's disease. Br Med J (Clin Res Ed.) 289: 954, 1984.

SONNENBURG JL, XU J, LEIP DD, CHEN C-H, WESTOVER BP, WEATHERFORD J, BUHLER JD, GORDON JI: Glycan foraging in vivo by an intestine-adapted bacterial symbiont. Science 307: 1955-1959, 2005.

STOLL B, HENRY J, REEDS PJ, YU H, JAHOOR F, BURRIN DG: Catabolism dominates the first-pass intestinal metabolism of dietary essential amino acids in milk protein-fed piglets. J Nutr 128: 606-614, 1998.

STROBER W, FUSS IJ, BLUMBERG RS: The immunology of mucosal models of inflammation. Annu Rev Immunol 20: 495-549, 2002. 
SU L, SHEN L, CLAYBURGH DR, NALLE SC, SULLIVAN EA, MEDDINGS JB, ABRAHAM C, TURNER JR: Targeted epithelial tight junction dysfunction causes immune activation and contributes to development of experimental colitis. Gastroenterology 136: 551-563, 2009.

THYMANN T, BURRIN DG, TAPPENDEN KA, BJORNVAD CR, JENSEN SK, SANGILD PT: Formula-feeding reduces lactose digestive capacity in neonatal pigs. Br J Nutr 95: 1075-1081, 2006.

TSUNE I, IKEJIMA K, HIROSE M, YOSHIKAWA M, ENOMOTO N, TAKEI Y, SATO N: Dietary glycine prevents chemical-induced experimental colitis in the rat. Gastroenterology 125: 775-785, 2003.

UNUTMAZ D, PULENDRAN B: The gut feeling of Treg cells: IL-10 is the silver lining during colitis. Nat Immunol 10: 1141-1143, 2009.

VICARIO M, AMAT C, RIVERO M, MORETÓ M, PELEGRÍ C: Dietary glutamine affects mucosal functions in rats with mild DSS-induced colitis. J Nutr 137: 1931-1937, 2007.

YANG X, YANG C, FARBERMAN A, RIDEOUT TC, DE LANGE CF, FRANCE J, FAN MZ: The mammalian target of rapamycin-signaling pathway in regulating metabolism and growth. J Anim Sci 86: E36-E50, 2008.

YOUNG D, IBUKI M, NAKAMORI T, FAN MZ, MINE Y: Soy-derived di- and tripeptides alleviate colon and ileum inflammation in pigs with dextran sodium sulfate-induced colitis. J Nutr 142: 363-368, 2010. 